\title{
Will the 'Shire' ever be the same again? Schooling Responses to the Cronulla Beach Riot
}

\author{
Carol Reid \\ Centre for Educational Research, University of Western Sydney
}

\begin{abstract}
In the aftermath of the Cronulla Beach riots, schools were faced with the fallout of social conflict, including having to deal with widespread fear and confusion both in their local communities and among students. This was especially the case for schools in the Sutherland Shire and in the local government area (LGA) of Bankstown. Apart from the presence of many young people in the initial riot and the revenge raids, some schools, like churches, had been the target of attacks (Leys and Box, 2005: 1; Daily Telegraph, 2005: 5). Schools were also targeted as places to battle the consequences of cultural division: the then Prime Minister John Howard, in his Australia Day speech just over a month after the riots, complained that the teaching of Australian history in schools needed reform to properly foster the core values that would bind a nation together (Sydney Morning Herald, 2006). At all levels of government, a raft of programs designed to ease local tensions were introduced, many of which focused on young people or on schools (see Board of Studies New South Wales, 2007; Surf Life Saving NSW, 2006). Schools are central to understanding the consequences of these events largely because they are places where the congregation of young people offers a rare medium for the tasks of responding to diversity, inequality and change in an increasingly globalised world. They are also institutions in which debates around values, social cohesion and national identity have become central concerns.

This article outlines the contexts for understanding the role of schools: both in terms of the spatial dynamics of the 'Shire' and in terms of the changing nature of educational policy. It suggests that these contexts produce both a degree of cultural heterogeneity in young people's social lives and a degree of segregation amongst young people in schooling which delimits 'what is possible' in terms of schooling responses to the Cronulla Beach riot. It then focuses on a National Values Education Project ${ }^{1}$ (NVEP) involving five schools in south and south-western Sydney as a direct response to the Cronulla Beach riot and its attempt to use the Values Education framework as a conduit to increased understanding of what it might mean to live in the current social context of this part of the Sydney metropolitan area, including experiences of 'cultural dissonance' and conflict.
\end{abstract}

\section{The local and the global}

The beach has long been a site of social tensions and conflict, especially amongst young people (Collins 2009). Cronulla in particular has a long history of defending its territory against 'outsiders' visiting on weekends:

Bruce Baird, former federal member for Cook that takes in Cronulla, remembers the days when the 'surfies fought the westies' but the weekend riots he believes are different. He says the atmospherics changed after September 11, Tampa and

\footnotetext{
${ }^{1}$ Clusters of schools from around Australia were selected to design, implement and evaluate quality projects in values education which would reflect and utilise the National Framework in local contexts. The projects, managed by Curriculum Corporation, centred on using action research methodologies to encourage improved values education practice for all Australian schools.
} 
the Bali bombing. 'There is a memorial to six young people who died in the Bali bombing right where the riots took place,' he said. (Skelton, 2005)

What makes the contemporary struggles different to these earlier fights over space by different sub-cultural groups is that they are now not only between suburban 'outsiders' and 'insiders' for this division has become racialised: the outsiders are now considered 'unAustralian'. While the struggle over space is not new in Sydney or more specifically Cronulla, it has taken on a different inflection. This shift has occurred partly because of the changing ethnic character of the 'westies' (Collins 2009), but also because of the significance of the Shire in the nation's history. The Shire is home to specific colonial narratives, including the White sacred site: the landing place of the first White 'discoverer' at Captain Cook’s Landing Place, Kurnell. Kurnell Peninsula is often called The Foot, the place where Cook's foot first connected with Aboriginal land. Furthermore, the 'Shire' has been cushioned from the changing ethnic composition of Sydney by its location, relative wealth and the fact that people are not as geographically mobile. Families commonly have multiple generations staying in or returning to the local area, children go to local schools and there are few private schools. In many ways, it represents a kind of heartland of 'Australianness'.

It would, however, be naïve to suggest that people living in the Shire are ignorant of global events and the changing ethnic composition of Sydney. Yet, as a geographically isolated peninsular and as a largely middle class and White space where a number of the Bali bombing victims' families live, Cronulla represents a peculiar case of not just the junction of the local and the national, but also how the local and the global intersect - what is often referred to as 'glocalisation'. This collision of social and cultural change is neither simply inevitable nor catastrophic, but entails the transformative potential of anxieties, fears and hopes in contexts where teachers and students struggle with the experience of glocalisation, wider cultural dissonance and conflict (Carrington 2002).

The spatial dynamics in the Shire are important to the educational responses to the Cronulla Beach riot as they provide insights into the ways in which 'people imagine and navigate racialised space in their own way' (Alexander \& Knowles 2005, p.5). In the quote above, Baird, for example, sees difference in the parallel narratives of past fights but there are also continuities in terms of the struggle over space, identity and race. The original colonial 
footprint was here on Aboriginal land after all - something that is often erased from collective memories through a focus on the newer, more urgent dynamics of racialisation.

\section{The shifting sands of educational policy}

Schools are not safe havens remote from the forces of social change, international conflict, and debates around national cohesion. Indeed, they are at the centre of the tensions produced by these processes. Since the late 1980s, for example, the shift in education policy in NSW to increase school 'choice' exemplifies one aspect of the contradictions of glocalisation. School choice has turned education into a market place (Marginson 1997) and parents have become increasingly mobile in the search for 'good schools' (Gulson 2006). While the rhetoric has been around 'schools of the future [becoming] social and educational centres of communities and builders of social capital of the local communities they serve' (Riordan 2005, p. 186), in practice the policies of school choice have led to increasing homogeneity in some schools while demographic change has produced high degrees of cultural diversity in others. Research indicates that a number of schools in Sydney are increasing in ethnic concentration (McDougall 2009; NSW Department of Education and Training 2008), including those in the Bankstown LGA, while schools in the Shire remain dominated by Anglo-Celtic/Saxon ethnic groups. After the riot there was also a degree of 'White flight' out of the areas where school students were mainly from 'Middle Eastern' backgrounds (Bonnor \& Caro 2007) into schools located in the Shire (Patty 2008). This has occurred, as Patty points out, alongside the state's encouragement of private schools catering to particular religious orientations, another dimension of the marketisation of schooling and the rhetoric of choice.

Connell (2003, p.246) found in a study of the changing secondary school system that 'school choice probably speeds up processes of ethnic concentration and segregation for other reasons too, such as families from a particular immigrant group bringing their children together for mutual support'. Yet, while we see that religious and minority ethnic identified schools are growing we often overlook the fact that it is also the dominant 'White' group of parents, particularly the middle classes, that are bringing their children together to ensure social mobility at a time marked by greater competition and the increasing risks associated with glocalisation (Butler \& Hamnett 2007). Place and school therefore become important as a signifier of racialised privilege and can be symbolic of White power. Yet, this power is often invisible and despite research into racialisation in schools there is inadequate analysis 
of Whiteness as the norm (Troyna 1998,p.334). This is because the cultural practices, behaviours, demeanours, language and aspirations of the dominant group are considered to be how things should be 'naturally'.

The Cronulla Beach riots, however, made this Whiteness visible. Perera (2006) contends that the riots revealed White people's territorial claims. The wearing of T-shirts with the slogans 'We Grew Here! You flew here' and 'Aussies Fighting Back’ brought to the foreground White nationalisms. This territorialism was also gendered and became the basis of popular claims about the causes of the conflict - how young white men viewed treatment of 'their' women by Middle Eastern men, how the beach should be used for particular activities and how bodies should be displayed and carried in the beach (including issues of decency, body hair and deportment). These are essentially racialised discourses that have become normalised through the absence of overt racial categories. As Troyna (1993, p.29) put it: 'This covert use of racial evaluations serves important political purposes... because it is often capable of 'justifying racial discrimination by providing other non-racist criteria for the differential treatment of a group distinguished by its racial characteristics'. However, this covert use of racial categories disappeared after the riot and exposed the underbelly of Whiteness. The treatment of women, the use of public space and the safety of families were all at some stages presented in terms of Western standards of conduct, but in doing this they brought to the surface deep investments in Whiteness.

These anxieties also fed a wider social anxiety about multiculturalism, social cohesion and cultural values. The comments made by John Howard (and other politicians) rejecting a claim about the racism of Australian society (Sydney Morning Herald 2005) strengthened claims that there was a need to reaffirm the core values of Australia's western liberal democracy. That is, by criticising the 'bad values' (especially towards women) of Lebanese youth, not only made it clear who the 'problem' was, but how the reform of schooling was seen as a necessary national project (Howard 2006). Howard's call to return to teaching history which celebrated a narrative of national progress was not a simple kneejerk reaction, but part of a longer term educational agenda, seen in the growth of civics education and values statements. The focus on anti-racism and programmatic multiculturalism in Australia has been largely replaced by values and citizenship education (Leeman \&Reid 2006). Values education programs at all levels - state and federal - provide funding for projects that incorporate action research for teachers, across a number of school sites, with university academics. 
These same projects produce curriculum materials following a series of planned educational experiences with students and teacher professional development. Civics Education is largely concerned with the history of the nation and provides units of work for students in primary and secondary schools in the Discovering Democracy Units (Curriculum Corporation 2009).

The racialised relations around territory and gender, then, were connected to an agenda around national identity, education and values. So here was a paradox: a nationalist agenda constructed around a particular view of social life as a singular historical narrative sitting alongside policies of school choice, which created a proliferation of differences - geographic, economic, class, cultural and religious. This disjuncture in policy delimited what was possible in schooling responses to the riot and emphasised the importance of place.

\section{The importance of place in school responses}

We were given intelligence by the local police command to say that there was a planned school invasion. A large number of people from the Bankstown area were planning to invade the school and they had a couple of names of kids that they'd allegedly wanted to get. (Cited in Burridge \& Chodkiewicz, 2008, p. 33-34)

In the days after the Cronulla Beach riot, conflict spilled out into other suburbs of Sydney, and included attacks on shops, in residential areas and streets. Churches and schools were particular targets of attack (Australian 2005; Daily Telegraph 2005). One school in the Shire had to close down for two days (Burridge \& Chodkiewicz 2008). Such reprisals and threats continued for some period of time, and in the aftershock, schools were a key institution that had to deal with the longer term effects, including the impact on local communities. The emotional roller-coaster for families, students and teachers in the Shire and the Bankstown LGA as they grappled with these difficult legacies required a response that could enable an exchange of knowledge, the voicing of concerns and the release of fraught emotions. As Wievorka (2004, p 59) argues, a sense of one’s cultural traditions being threatened by the outside world is one of the sources for racist action. So, small scale responses in schools are as important to examine as the broader social, economic and legal frameworks, because these responses entail forms of negotiation that address sources of conflict and injury.

Such responses need to be understood as grounded in 'place' despite the increasing significance of globalisation, because it is through local spaces that cultural transformation is 
made tangible and sustainable or is opposed. In exploring the significance of place, Thomson examined UK community-school projects that bring together people who might otherwise never meet to work on something of community benefit. In her study, students worked with 'ferals, ${ }^{2}$ to develop a park and 'at risk' youth worked with local elderly men to construct a fair ground. Thomson found that 'students in these projects were also brought together with significant cultural institutions and cultural capital in ways which allowed them to critically encounter local/national narratives’ (2006, p.89).

In situating place as a central dimension and dynamic in educational responses to the Cronulla Beach riot many activities and events involved schools and communities. A number of place-based interventions related directly to the beach, including Surf Life Saving NSW's educational program On The Same Wave ${ }^{3}$ which aimed to train a more culturally diverse group to become lifesavers, and the 'Peace on the Beach' event that brought together Shire public schools with Islamic schools or schools with predominantly Middle Eastern students. Attempts at dialogue and reconciliation were between geographically dispersed schools, across systems and on each other's turf. Place thus assumed an important dynamic in constructing a socially just curriculum given the increasing separation and segregation of young people in schooling, despite the wider context of diversity, based on geography, class, gender, religion, ability and ethnicised and racialised differences.

\section{Case study - the Unity in Diversity project}

Given the spatial dynamics created and revealed in the riot and its aftermath, a 'place-based' project was developed with schools in the Bankstown LGA and Sutherland Shire. The Unity in Diversity project was initiated with the explicit aim of addressing many of the critical issues that emerged in the wake of the Cronulla Beach riots and brought together five schools - two Islamic and three public - and a group of staff at the University of Western Sydney. It was funded under the Australian Government's National Values Education Program (NVEP), which worked with selected clusters of schools from around Australia to design, implement and evaluate projects in values education using the National Framework for Values Education in Australian Schools (Department of Education, Employment and Workplace Training 2005). Funding allowed teacher’s release from teaching time to gain professional

\footnotetext{
${ }^{2}$ A commonly used term in Australia for youths who have dropped out of mainstream society to live a communal 'hippie' style life, frequently politically engaged and involved in militant 'green' action.

${ }^{3}$ The NSW program was the first part of a national strategy. See Surf Life Saving Australia (2006).
} 
development, plan and organise collaborative projects and to purchase and develop resources that developed an understanding of values. Funding also paid for a University Academic Network partner to develop and document an action research project, which was central to the learning and development of school staff engaged in the project.

A cluster of schools across systems (private and public), religion, levels (primary and secondary) and geographic regions were brought together to build relationships between the clusters' communities to re/build respect for individual identities and respect for other cultures. There were two high schools (one Islamic and one public with a high number of Islamic students from the Bankstown LGA) and 3 primary schools (one Islamic and one public from Bankstown LGA; one from the Shire). One other public high school from the Shire participated at an event at Gunnamatta Bay. Overall there were over 500 students involved; around 20 teachers and more than 50 parents.

Key teachers ${ }^{4}$ from these schools met several times over a two year period with academic partners from UWS using an action research methodology. This methodology was constructed by Curriculum Corporation who was managing the NVEP for the former Department of Education, Employment and Training. There were also two national meetings with other project teams in Melbourne and Kingscliff, NSW. Meetings were recorded in a number of ways - audiotape, notes and teacher written narratives. There were focus groups with parents and students at each participating school (audio taped) as well as photographs and a film taken during four collaborative events between schools. Data analysis went through a number of readings: thematic, interpretive and extractive - whereby illustrative pieces of text, which represented themes and concepts, were selected. Central to this analysis was a focus on power so that culture or 'race' is not a definer of a community (Ramji, 2009, pp.73-75).

Considerable debate between participating teachers and academics resulted in the desire for the project to avoid becoming 'preachy' about values education and to enable social literacy through carefully constructed activities. Students were involved in four days of collaborative, inter-school activities as well school-based values education programmes. The collaborative learning experiences were a Surf Awareness Day at Cronulla, a Web-building workshop at a

\footnotetext{
${ }^{4}$ School-based values education coordinators
} 
Cronulla public school, a 'Developing a sense of self and others' day at Bankstown Civic Centre and a day entitled 'Crossing The Bridge: A Conversation at Gunnamatta Bay’.

Parents participated in focus groups at each school to gain understandings about the impact of the riot on their communities, families and children. The outcomes of these discussions were intended to inform values education programs in each participating school. In addition, focus groups of parents and teachers were held at Gunnamatta Bay on the specific topic of what it means to be and feel Australian as well as rights and responsibilities of Australian citizenship.

At the outset this cluster came together with diverse expectations. One Islamic College was particularly interested in environmental education and had worked on a Peace Garden with another local high school. Two schools in the cluster had already met at a 'Peace on the Beach’ event at Cronulla. One of these schools took the lead with the development of a project website. Two other schools - a high school and feeder primary school - were interested in issues related to transition to high school and in the multiple forms of literacy that they might continue developing in their students, who were largely Islamic but in public schools.

A major aim of the second stage of the NVEP, which this project was part of, was to address values in intercultural and global contexts. The cluster had a specific focus on understanding how difference might be conceptualised and responded to in a way that did not erase difference or seek to diminish its importance to individuals. At the same time, there was an expressed desire to understand how Values Education specifically could respond to or provide the conduit through which this process might be achieved. In discussions, Curriculum Corporation also wanted to understand how Values Education might deal with 'cultural dissonance'.

While the riot may have been a consequence of cultural dissonance, it is important to emphasise that it does not automatically follow that the children in the schools in these schools felt this way. While there were legacies of fear and uncertainty conflict could not be assumed among students from each school. To assume that this is the case is to rely too heavily on the idea that race or culture is static and that putting groups of culturally different students together will automatically result in tension (cf Miles 1993). This is not to suggest 
that young people don't experience forms of disaffection, but to recognise that more is at stake here than simple binaries of cultural difference. As one teacher commented at an early discussion, 'Children are confused - from my observations' so there were very difficult moral and social questions being posed within schools, families and communities. As another teacher explained:

I had a delegation after the text messages [to join retaliation to the Cronulla Beach riot]. Students said: 'We don't know what to do. These are what we are getting and we want to defend ourselves but don't know if this is the right thing?' What are the consequences? Is revenge justifiable?

These kinds of value-laden philosophical questions were important to respond to and in considering how the students' might find less violent ways to react, an Islamic high school teacher suggested that students from schools in the Shire and the Bankstown LGA:

...jointly publish a letter in a newspaper. The measurement when you start out is to record what they expect or hope for from working with another school. At the end reflect back on what they have learned.

After discussing this idea, the same teacher said that it probably wouldn’t work as her students wouldn’t expect to get a letter published. A teacher from Cronulla said:

Mine would have an expectation that they would get published.

To which the former replied:

We need to address issues of empowerment.

The above example demonstrates the way in which students from one of the Islamic high schools felt following the riot. That is, they felt that their voices would not be heard because they would either not be believed or not have access to mainstream media whereas students from the Shire school clearly felt that their access to the media was assured. It is interesting to consider why this expectation is already strongly embedded in children's thinking and it points to the unequal distribution of various forms of social power following the riot. Henry and Tator (2002) in considering media access in the Canadian context argue that middle class Whites are more able to access media opportunities due to their closer alliance with dominant cultural values and norms. In the highly emotive context following the riot and the construction of Middle Eastern males as lacking in such values and norms, it is perhaps not surprising that young men from the Islamic high school felt they had no voice. 
Parents of students in the schools in this project also felt the changed spatial dynamics in Sydney following the riot. Cronulla and Bankstown now bore what Back (2005) calls the mark of racial grafts. That is, Cronulla was a White space and the Bankstown LGA was a Middle Eastern space. This emerged in discussions with groups of parents in all the schools. For Muslim parents, fear was an overwhelming consequence of the riot - fear for themselves, friends, community well-being and their children, especially if they were to visit or return to Cronulla. However the flipside of fear was a feeling of loss, particularly parents from Cronulla who missed Muslim families coming to Gunnamatta Bay for their picnics. Parents felt fear because the riot and the ensuing debates highlighted issues related to dress, especially for women being judged or heckled because they wore a hijab or a bikini. The women were concerned about cultural assumptions ('oppressed' v. 'loose') resulting from their use in public space. Many parents were worried about their children going to different areas of Sydney after the Cronulla Beach riot given the threat of further violence.

In attempting to respond to these concerns, a number of collaborative projects were developed to overcome the considerable emotional affects generated by the Cronulla Beach riot. One of the key aims became 'geographic', or rather, to counter the boundaries created geographically as expressed by the parents and teachers.

\section{Surf Awareness Day}

One of the first collaborative projects was a Surf Awareness Day at Cronulla. This understandably presented a challenge for parents from the Bankstown LGA - many of whom were Muslim - because it meant their children visiting the site of the riot. Seventy-five students from Muslim and other backgrounds as well as Anglo-Celtic/Saxon students attended the day together to focus on cultural practices at the beach. This meant that appropriate swimwear for young Muslim girls had to be designed and halal food needed to be organised. Students participated in joint 'cross-cultural' team activities on the beach, received instruction on surf safety and generally gained knowledge about the culture of the beach. The majority of the 75 students who participated in a post-activity survey developed by teachers in the cluster said that they learned what a rip was and that the flags meant it was safe to swim in that area. For them this particular event was an ice-breaker in a space that had become associated with violence, exclusion and alienation. The success of the day was 
evident in turning their perspective around and, at the same time, laying the foundation for future collaborative projects.

\section{Web-building workshop}

Students also used new forms of technology to foster interaction. A collaborative intranet website was designed by 18 students representing all schools to establish a place where students could visit one another online and discuss impressions of activities of the project. The virtual space encouraged students to challenge stereotypes being presented in the mainstream media through developing an image for the home page, requiring considerable discussion of visual representation and privacy. For these students this connected with their lived experiences more than the disconnected reports they were reading in the media. The process required unsettling some preconceptions (on all sides). The following comments on the blog reveal some of this process:

We felt nervous at first, however, meeting other people made us more confident.

I learnt that everyone thinks in a different way. I also learnt that the other schools have as much of a right to be here. I learnt that no matter how different a person is you can learn to co-operate with them.

The cluster maintained the website over the duration of the project, recording the ongoing activities and encouraging students to respond to a number of on-line surveys and participate in blogs. In total around 110 blogs and survey responses were recorded. One of the main difficulties with this website however was its location on the NSW Department of Education and Trainings' server, which limited access to students outside of state schools. Once again, the consequences of a segregated schooling system limit what is possible in responding to the riot.

\section{Developing a sense of self and others}

In another event over 100 students and staff came to Bankstown Town Hall to participate in a range of activities designed to give students a better understanding of themselves and others. The day began with a performance about bullying and racism (cyber, physical, mental and verbal), which was followed by activities facilitated by Bankstown Youth Development Services. These included Photographing Values in the Community, Creative Writing, Environmental Art, Music, No Racism Rap and Hip Hop, Filmmaking and Interview 
techniques. These different projects produced collaborative products where stories of migration, family, antiracism, environmental action and bullying were central. For the parents of students from the Shire, allowing their children to visit Bankstown caused similar concerns that visiting Cronulla had raised for those from Muslim parents in the Bankstown LGA. However, some of the comments of students from the Shire posted on the blog reveal the impact of the day:

The things that I learnt about the day were that there is more than one way of hurting someone and not every body has the same skin colour or hair colour. Also I learnt how to work with other people from other schools and other cultures.

What I got out of the day was that I am very different to the people that I talked to. They had a different religion, played a different sport, liked different music and so on. But I still made friends with them. The only thing we had in common was we went for the Souths [football team].

The great thing about the day was that I had a blast of fun, but I also learned about what I have in common with these students such as some of their laws and customs. Also that it is so fascinating the way they are able to speak another language.

There was considerable social and cultural capital brought together in this project in the form of community workers and activists experienced in many of the issues raised because they had worked in the Bankstown LGA dealing with marginalised youth. Some of the content of this day was confronting, such as the bullying performance. It contained language and concepts that were at times an affront to staff from some schools because of references to sexuality and bodies. However, it was generally agreed that the impact on students was positive and that it had moved them forward in a way that needed to be continued.

\section{Crossing the Bridge: A Conversation - Gunnamatta Bay}

Very early in the project the environment was seen to be a useful focus, for all students could work together and overcome the territorialisation and divisions evident in the riots and move beyond ethnicity and consider community as a whole. Gunnamatta Bay - a key site for Muslim family picnics prior to the riot - was chosen, partly because it was known and also because it presented environmental challenges such as water requiring anti-pollution 
activities. The area also had a strong history of Indigenous occupation as well as a large hall for silent conversations (noise pollution) and the dialogue groups.

Just over 120 students engaged in a range of activities such as water conservation, drama and silent conversations using photographs which later fed into the 'conversations' activity. A group of students from six Liverpool district high schools that had been part of an anti-racism project funded by a Department of Immigration and Citizenship ‘Living in Harmony’ grant conducted focus groups with the students around issues of racism, multiculturalism and social inclusion. The questions discussed were: 'What makes you Australian?' and 'What does it mean to be Australian?' Parents and teachers held separate discussions while students participated on their own. Some of the comments on the blog were:

This magnificent day was to cross the bridge of our religions. I learnt many values but my favourite was the value of the hijab. I think this day was beneficial. No more us and them.

I said that I most feel Australian when I'm watching the Australian Sport teams play and when I'm with my friends.

What I most liked about the day was bonding and playing with kids from different cultures and communities. I think there should be more days like these because it is great fun for us to learn and tell kids about our lives and our cultures.

\section{The limits to values education}

By the time this last activity was completed many of the students had formed friendships across schools and had come to understand more deeply what was fair and not fair in terms of cultural difference but less about how racisms were produced beyond interpersonal relations. To some extent this can be understood as one of the weaknesses of values education. The project achieved its goals of providing an opportunity to explore differences and sameness and break down barriers, which were significant consequences of the Cronulla Beach riot yet it failed to move beyond the ‘human relations approach’ (Sleeter \& Grant 1987). In this approach the focus is on 'managing differences', which often produces a focus on the 'otherness' of students' difference. We can see this in some of the students' comments.

Values education, as a conduit for intercultural understanding is based on similar foundations to pluralistic or liberal multiculturalism, which relies on fixed notions of culture as bounded 
entities based on ethnicity alone. The problem with this is that it often serves as a form of regulation and fails to problematise whiteness as the cultural norm (Troyna 1998) as well as often reproducing stereotypes (cf May 1999 for full discussion). There is no challenge to the status quo so that relations of power might be revealed, such as those articulated by the young Muslim males who felt their voices would not be given space in the mass media. This is the essential paradox of liberalism, that it 'tolerates diversity only as an instrumental quality and not as something valuable in itself' (Griffiths 1993, p. 309). A preferable approach would be to look at the recognition of diversity within the current structures but also develop a political literacy that links these struggles to issues of wider social justice (Leeman \& Reid 2006, p.58). In a critical approach, issues of identity and nation become central to analysis.

\section{Conclusion}

The Cronulla Beach riot sent a tremor across Australian multicultural society, exposing the cracks in inter-ethnic youth relations in Sydney. An understanding of how to respond to these challenges to diversity is as important as understanding what happened and why. Schools are an important and potentially fertile site in responding to these issues. This article set out to examine schooling responses to the Cronulla Beach riot by analysing one 'values education' program that included schools in the Cronulla Shire and Bankstown LGA, the areas of Sydney that were most affected by the riot.

The tangible outcomes of the project included a DVD, a website, teacher narratives, curriculum resources and a report. The project also brought together students and parents from both sides of the spatial, class and education system divide to explore ways of moving forward from the divisiveness expressed in, and encouraged by, the Cronulla beach riot. This provided the opportunity for many students to encounter and challenge some of the local narratives that had affected their construction of Cronulla and Bankstown. The project was successful in terms of the participants who stated that the cultural and spatial stereotypes that they previously held were replaced by a greater mutual understanding and respect. Strategies and models for developing better intercultural understandings and for beginning to heal the fears and bitterness that emerged during the Cronulla Beach riots were trialled and refined.

However, it was also apparent that using values education as a conduit for responding to cultural dissonance is constrained by a number of broader, society-wide, factors. Two main ones come to mind. First, values education has a focus on individual social relations thus 
limiting understanding of the causes of cultural dissonance to the interpersonal context.

Second, the segregation of students into different schooling systems - private, public, religious and secular - revealed the systemic differences in resourcing between public and private sectors. More generally, growing segregation in schooling builds divisions in increasingly diverse communities. Against this trend, individual projects such as the ones explored in this chapter, no matter how successful, appear to be swimming against the tide. As a consequence there needs to be a better understanding of power relations and education and the way that increased inequality in education resources and outcomes builds divisions in society - at once inter-ethnic and inter-class - rather than overcoming them. Put another way identity choices are not available to all individuals or groups equally because class, ethnic and gender stratification, objective constraints and historical factors structure them (Leeman \& Reid 2006, p.58). The responses to the Cronulla Beach riots for Sydney’s schools and communities require deeper re-evaluations of Australia’s education system.

\section{References}

Alexander, C. \& Knowles, C. 2005, 'Introduction', in C. Alexander \& C. Knowles (eds), Making Race Matter: Bodies, Space and Identity, Palgrave MacMillan, Basingstoke, Hampshire, pp. 1-15.

Back, L. 2005, ' “Home from Home”: Youth, Belonging and Place', in C. Alexander \& C. Knowles (eds), Making Race Matter: Bodies, Space and Identity, Palgrave MacMillan, Basingstoke, Hampshire, pp. 19-41.

Board of Studies New South Wales 2007, Respect and Responsibility: Promoting Values in Education, http://www.boardofstudies.nsw.edu.au/respect/ [accessed 30 May, 2008]

Bonnor, C. \& Caro, J. 2007, The Stupid Country: How Australia is Dismantling Public Education, University of New South Wales Press, Kensington.

Burridge, N. \& Chodkiewicz, A. 2008, Representations of cultural diversity in school and community settings, Centre for Research in Learning and Change, Faculty of Arts and Social Sciences, University of Technology, Sydney.

Butler, T. \& Hamnett, C. 2007, 'The Geography of Education: Introduction', Urban Studies, vol. 44, no. 7, pp. 1161-1174.

Carrington, V. 2002, New Times: New Families, Kluwer Academic Publishers, Dordrecht.

Collins, J. 2009, 'Sydney's Cronulla riots: the context and the implications' in G. Noble (ed) Lines in the Sand, Sydney Institute of Criminology Series, no 28, pp. 23-27.

Connell, R.W. 2003, 'Working-class families and the new secondary education', Australian Journal of Education, vol. 47, no. 3, pp. 235-50.

Curriculum Corporation 2009, Discovering Democracy, http://www1.curriculum.edu.au/ddunits/index.htm

Daily Telegraph 2005, 'Teachers' cars hit by gunshots', Daily Telegraph, 14 December, p. 5.

Department of Education, Employment and Workplace Training 2005, National Framework for Values Education in Australian Schools http://www.valueseducation.edu.au/values/default.asp?id=8757

Gulson, K. 2006, 'A White Veneer: Education policy, space and "race” in the inner city', Discourse: studies in the cultural politics of education, vol. 27, no. 2, pp. 259-274. 
Henry, F. \& Tator, C. 2002, Discourses of Domination: Racial Bias in the Canadian Englishlanguage Press, University of Toronto Press, Toronto.

Howard, J. 2006, 'Australia Day Address to the National Press Club’, 25 January, http://www.australianpolitics.com/news/2006/01/06-01-25 howard.shtml

Leeman, Y. \& Reid, C. 2006, 'Multi/Intercultural Education in Australia and The Netherlands', Compare, vol. 36, no. 1, pp. 57-72.

Leys, N. \& Box, D. 2005, 'Now churches are targeted - Race-war rioters turn on religious differences', Australian, 15 December, p. 1.

McDougall, B. 2009, 'Languages of learning', Daily Telegraph, 6 February, p. 3.

Marginson, S. 1997, Markets in education, Allen and Unwin, St Leonards.

May, S. 1999, Critical Multiculturalism: Rethinking Multicultural and Antiracist Education, Falmer Press, London.

Miles, R. 1993, Racism after 'race relations', Routledge, London.

New South Wales Department of Education and Training 2008, Statistical Bulletin: Schools And Students In New South Wales, 2007 [accessed 8 February, 2009]. https://www.det.nsw.edu.au/media/downloads/reports_stats/stats/statsbulletin/stat2007.pdf

Patty, A. 2008, 'White flight from our schools', Sydney Morning Herald, March 10, p. 1.

Perera, S. 2006, 'Race, Terror, Sydney, December 2005’, Borderlands, vol. 5, 1. http://www.borderlands.net.au/vol5no1 2006/perera raceterror.htm

Ramji, H. 2009, Researching Race: Theory, Methods and Analysis, Open University Press, Berkshire, England.

Riordan, G. 2005, Schools Embedded in Communities: The Future of Public Education in New South Wales, University of Technology, Sydney, Ultimo.

Skelton, R. 2005, 'Bali, Tampa, 9/11: a potpourri of causes', Age, December 12 http://www.theage.com.au/news/national/bali-tampa-911-a-potpourri-ofcauses/2005/12/12/1134236003147.html [Download 13.12.05]

Sleeter, C. E. \& Grant, C. A. 1987, 'An analysis of multicultural education in the United States', Harvard Educational Review, vol. 57, no. 4, pp. 421-44.

Surf Life Saving Australia 2006, On The Same Wave - A Living In Harmony Initiative, http://www.slsa.asn.au/default.aspx?s=_onthesamewave

Surf Life Saving New South Wales 2006, On The Same Wave - Promoting Safety And Diversity On Australia's Beaches, http://www.surflifesaving.com.au/www/463/1001127/displayarticle/on-thesame-wave--1001254.html

Sydney Morning Herald 2005, 'PM refuses to use racist tag', Sydney Morning Herald, December 12, http://www.smh.com.au/news/national/pm-refuses-to-use-racisttag/2005/12/12/1134235985480.html

Sydney Morning Herald 2006, 'PM appeals for tolerance’, Sydney Morning Herald, January 25, http://www.smh.com.au/news/national/pm-appeals-fortolerance/2006/01/25/1138066839181.html?page=fullpage\#contentSwap2

Thomson, P. 2006, 'Miners, diggers, ferals and show-men: school-community projects that affirm and unsettle identities and place?', British Journal of Sociology of Education, vol. 27, no. 1, pp. 81-96.

Troyna, B. 1993, Racism and Education, Open University Press, Buckingham.

Troyna, B. 1998, “"The whites of my eyes, nose, ears...”: a reflexive account of "whiteness” in racerelated research', in Connolly, P. \& Troyna, B. (eds) Researching Racism in Education: Politics, Theory and Practice, Open University Press, Buckingham, pp. 95-108.

Wievorka, M. 2004, 'Research racism, French social sciences', in Bulmer, M. and Solomos, J. (eds) Researching Race and Racism, Routledge, London, pp. 52-65 